\title{
Family-Friendly Human Resource Management Practice and Employees' Behavioural Outcomes in Nigerian Banking Sector
}

\author{
Dayo Idowu Akintayo Olalekan Ishola Ayantunji \\ Kolawole Sunday Ajibola* Toyin Solomon Olaniyan \\ Faculty of Management Sciences, College of Management and Social Sciences, Osun State University, Okuku \\ Campus,Nigeria
}

\begin{abstract}
This study investigated the impact of family-friendly human resource practice on employees' behavioral outcomes (organizational commitment, job performance and workplace spirituality) in Nigerian banking sector. 239 bankers participated in the study. The study employs cross-sectional survey research design. Questionnaire was used to obtain the relevant data. The study used simple random sampling method. The collected data were analyzed using Pearson Product Moment Correlation, Regression and T-test analyses with the aid of statistical package for social sciences (SPSS).The study found that there is a statistically significant contribution of between Family-friendly human resource practice (FFHRM) on Organizational Commitment ( $\mathrm{F} 1,237=46.003, \mathrm{p}<0.05)$. Further, it was found that there is a positive correlation between FFHRM and Organizational Commitment $(\mathrm{r}=.461 ; \mathrm{p}<0.05)$, job performance $(\mathrm{r}=.327 ; \mathrm{p}<0.05)$, and workplace spirituality $(\mathrm{r}=.253 ; \mathrm{p}<0.05)$. Workplace spirituality was found higher among female respondents than the male respondents. The study concluded that FFHRM is significant antecedent to employees' behavioral outcomes (organizational commitment, job performance and workplace spirituality) in Nigerian banking sector. Based on the conclusion, the study recommended that organizations should encourage and give FFHRM practice the priority it deserves and be willing to carry it out with new ideas.
\end{abstract}

Keywords: Family-friendly human resource practice, job performance, organizational commitment, workplace spirituality

DOI: $10.7176 / \mathrm{EJBM} / 12-11-04$

Publication date: April $30^{\text {th }} 2020$

\section{Introduction}

In recent times the introduction of family-friendly relationship has become a pressure that is fast arising in many organizations in Nigeria. Management of various organizations wants their employees in all stages to maximize their efforts to the fullest not considering what it will cost the employees and others factors that pertains to them been productive. For efficient and effective labour force, organizations in Nigeria are expected to provide an atmosphere that will conducive within and outside the organization. However, organizations in Nigeria are been faced with so many challenges such as global competition, development of information technology etc. The two main domains in human life are family and work. According to Gutek, Searle, and Klepa (2009) the two roles in those domains are conflictual.

The core of any society is family unit. Members of the family struggles with differs challenges arising from work and family responsibilities, hence, the pressures on the family. Family-friendly human resource is a potential tool that can be used by families and employers to cope with life issues and career in a competitive economy. Family-friendly human resource FFHRM policies in a workplace afford the employees the opportunity to successfully navigate more easily and strike a good balance between family and work demands. Cambridge Advanced Learner's Dictionary and Thesaurus (2020) specify that family-friendly human resource practice is also known as work-life balance (WLB) (Dessler, 2017). FFHRM "concerns the reconciliation of work, private and family life" (Kirton, 2017, p. 333).

There are three distinct categories of family friendly human resource practice: policies, benefits and services (Veiga, Baldridge, \& Eddleston, 2004). Family friendly practice takes into consideration work/family conflict related to work hours by offering a flexible around how, where and when work can be done e.g. flexible time, job sharing and flow of communication. Garrido (2016) found a significant impact of family-friendly policies on all types of employee job satisfaction. Likewise, Kopelman, Kossek and Ozeki (2006) found a positive relationship between the number of family-friendly policies offered by the organization and employee organizational commitment.

Organizational commitment $(\mathrm{OC})$ is the sense of responsibility of employees towards their organization. Dick (2011) defines OC as an attitudinal or emotive dimension of work motivation which can be seen in employee behavior at workplace. It is "the degree to which an employee identifies with the organization and is willing to put forth effort on its behalf" (Noe, Hollenbeck, Gerhart, \& Wright, 2016, p. 349).

Job performance is the assessment of whether an employee has done their job well. It's an individual evaluation measured based on a single person's effort. Individual performance is of high relevance for organization and individuals alike. Job performance has been defined as the overall expected value from employees' behaviors 
carried out over the course of a set period of time (Motowidlo, Barman, \& Schmit, 1997). The more job involvement, the higher the work-family conflicts; and its lead to increased burnout, lack of job satisfaction, and reduced commitment (Adams, King, \& King, 1996). The more preoccupied and reduced effectiveness due to that preoccupation, the higher the work family conflict (Akintayo \& Babajide, 2007).

Organizational commitment and job performance are components that are highly important to the development of an organization. When there is disequilibrium between the work and life balance of the employee it will hinder job performance and the level of commitment. Examples are when work life balance incentives like, leave entitlement, flexi time, and family and welfare policies, are not adhered to by the management. These may lead some employees to work round the clock with little attention to themselves and their families, which may result to broken home and poor parental upbringing. The personal issues that employees of face outside work, may demoralize them and in turn discourage them to be zealous in their service delivery to the organization and the customers.

Workplace Spirituality (WS) was a belief system that individual employee live their faith in the workplace (Cook, 2019). According to Wikipedia, one of the non-scholarly sources suggests that WS is a movement that started in the 1920s (Khanka, 2014). However, scholarly sources indicate that academic discourse on WS started around 1990 (Beehner, 2019). Workplace Spirituality is also known as spirituality in the workplace (Khanka, 2014). It means individuals and organizations attempting to live their values more fully in the work they do (Dehaghi, Goodarzi, \& Arazi, 2012; Khanka, 2014). Spirituality, according to Smith and Rayment (2007) in Biswakarma (2018) is an experience an employee will have that provides a feeling of support, inner connectedness to a supreme being.

Workplace Spirituality (WS) does not have universally acceptable definition (Beehner, 2019). However, there exist similarities among the most popular definitions advanced for WS. Denton (1999) had defined WS as an individual efforts geared towards finding fulfillment in the workplace and life. Hence, Giacalone and Jurkiewicz (2010) opine that WS can occur at individual, group, and or organizational level (Beehner, 2019). Workplace Spirituality has been described as a micro-glimpse of the organizational climate which is seen in the organizational culture (Shinde, Shinde, \& Lytle (2010), employee-family-friendly work environment laced with HRM activities that supports and nurtures the spirit of employee (Chatterjee \& Naqvi, 2010), as trait (Kinjerski \& Skrypnek, 2004 in Beehner, 2019).

Job performance (JP) is "actions and behaviors that are under the control of the individual that contribute to the goals of the organization" (Rotundo \& Sackett, 2002). Empirical study on the influence of FFHRM practice on OC and JP is limited. Also, study on the impact of workplace spirituality as an intermediary role on organizational commitment and job performance is also worthy of further in-depth study. According to the past research, workplace spirituality can promote the staff's job involvement (Riasudeen \& Prabavathy, 2011), job satisfaction, OC, and job performance (Rego \& Cunha, 2008). Consequently, it is imperative to examine the influence of FFHRM practice on employee behavioral outcomes in terms of organizational commitment, job performance and workplace spirituality (WS).

However, past researchers has reported that there is limited knowledge existing on how FFHRM practice can use workplace spirituality as a tool at work to influence employee behavioral outcome (organizational commitment and job performance), (Jianglin \& Xiuting, 2018; Gutek, Searle, \& Klepa, 2009; Kopelman, Kossek \& Ozeki, 2006; Hammer, Neal, Newsom, Brockwood, \& Colton, 2005). This study will be beneficial to understand the importance of FFHRM practice and workplace spirituality as well as how it generated outcomes in form of OC and job performance.

From the reviewed studies, it was established that WS can promote the staff's JS, OC, and job performance. Against the foregoing, this study investigated the impact of FFHRM practice on employee's behavioral outcome (organizational commitment, job performance and workplace spirituality). This is for the purpose of ascertaining the relevance of FFHRM practice on employee's behavioral outcomes in work organization in Nigeria.

In view of the above, the study investigated the impact of family-friendly human resource practice on employee's behavioral outcomes (organizational commitment, job performance and workplace spirituality) in the banking industry in Ogun and Lagos State in Nigeria.

\section{Empirical Review}

\subsection{Family-friendly Human Resource Practice and Organizational Commitment}

This is concern with whether family-friendly practices affect employee commitment as an outcome. In this sense, its importance is as an intermediate outcome. While commentators have suggested favourable links between family-friendly human resource practice and employees' commitment to the organization (and ultimately to business performance), there has been relatively little sets out to examine the more limited issue of whether familyfriendly working arrangements affect employees' commitment.

Ujma and Ingram (2019) investigated the role of task uncertainty on the perception of ability-motivationopportunity oriented HRM practices and organizational commitment. The study was carried out among in Poland 
among employees of 32 international recruitment and selection agency. The study found that HR practices that is geared towards motivating employees and availing them opportunities such as employee involvement within the organizations positively influences affective commitment and employee engagement (Ajibola, Mukulu, \& Simiyu, 2019).

A study on hotel and tourism industry that was conducted by Li, Mai, Yang, and Zhang (2019) was on the human resource management practices, emotional exhaustion, and organizational commitment. The study had 410 employees drawn from ten four/five-star hotels by the aid of convenience sampling technique hotel and tourism. The study used survey research design. The study found that HRM practices have positive significant impact on organizational commitment.

Cherif (2020) investigated the role of HRM practices and employee job satisfaction in predicting organizational commitment in Saudi Arabian banking sector. The study used quantitative survey research. Convenience sampling technique was used to select 330 respondents from three banks in Saudi Arabia. The study was cross-sectional. The study reported that HRM positively correlates with organizational commitment (Cherif, 2020).

In Pakistan, a study on human resource practices and organizational commitment: the mediating role of job satisfaction in emerging economy. A total of 218 respondents responses were used in the study. The samples were drawn from among white-collar, low and mid-level employees of four different telecommunication companies operating in Lahore, Pakistan. The study used SmartPLS software to analyze the data collected, structural equation model was used. The study found that HRM practices statistically significantly influence organizational commitment (Jawaad, Amir, Bashir, \& Hasan, 2019).

Aboramadan, Albashiti, Alharazin, and Dahleez (2020) investigated HRM practices and organizational commitment in Pakistan among employees working in higher education sector. The study found HRM practices as significant antecedent of employee organizational commitment. The study drew its 237 sample from academics and administrators. SEM was used in the analysis of data collected.

Family-friendly human resource policies and practices (FFHRPs) are provided by organizations to assist employees to balance the demands of their work and family commitments. Veiga, Baldridge and Eddleston (2004) proposed that there are three distinct categories of FFHRPs: policies, benefits and services. Family-friendly policies try addressing work/family conflicts related to working hours by offering flexibility around how, where and when work can be done (e.g., part-time work, job sharing, virtual working, Family-friendly human resource policies and practices (FFHRPs) are provided by organizations to assist employees to balance the demands of their work and family commitments.

Veiga, Baldridge and Eddleston (2004) proposed that there are three distinct categories of FFHRPs: policies, benefits and services. Family-friendly policies try addressing work/family conflicts related to working hours by offering flexibility around how, where and when work can be done (e.g., part-time work, job sharing, virtual working). Family-friendly HRM practice is expected to enhance OC, level of employee engagement, improve productivity in the workplaces.

\subsection{Family-friendly Human Resource Practice and Job Performance}

Mekhum (2020) investigate the influence of effective human resource management practices on organizational performance in the pharmacy sector of Thailand. The study sampled 650 respondents comprising of both operational employees and managers. The study used PLS SEM to analyzed the data collected. The study found that HRM significantly influence the employee job performance (Mekhum, 2020).

The implication of the findings is that FFHRM practice is capable of lowering the level of intention to leave among employees and increasing the level of employee job performance. Considering the proposition of PersonalOrganization Fit Theory and Work Adjustment Theory, family and work demands of the employees are met by those organizations that provide a home-like atmosphere and pleasant working environment. That on its own is capable of significantly improve employees' job performance and bring a more positive attitude and performance results.

Researchers have investigated the relationship between family-friendly human resource practice and organizational performance, voluntary turnover rate and labour productivity. They found that FFHRM policies have significant effects on increasing productivity, the number of FFHRM policies does not seem to decrease turnover rates, unionization significantly decreased turnover rate and increased productivity, and that an increased female employees are related to higher turnover rates.

\subsection{Family-friendly Human Resource and Workplace Spirituality}

Riasudeen and Prabavathy (2011) worked on the relationship between employee WS in manufacturing sector and their attitude. The study found that three dimensions of the workplace spirituality are all significantly positively related to job satisfaction, job involvement and employee organizational commitment (Riasudeen \& Prabavathy, 2011). 
On the basis of intrinsic motivation theory, workplace spirituality will have a positive effect on individuals' attitude and behaviour. Workplace spirituality by its very nature will meet the psychological needs of employees at work, which in turn serves as a motivator for beneficial behavioral manifestation to the organizations. Hence, FFHRM practice will positively predict employees' workplace spirituality.

According to Social Identity Theory, enhanced organizational identification raises individual outcomes such as the improvement of task performance and organizational citizenship behavior (Platow, Wenzel, \& Nolan, 2003). By promoting the well-being and interests of staffs actively, taking in consideration of employees' family responsibilities, creating a supportive and altruistic work environment, family-friendly human resource practice provides a positive psychological experience for employees, and empowers them develop a better sense of selfidentification, understand the meaning of work, and improve workplace spirituality.

Consequent upon the literature reviewed and in line with the objective of the study, the following hypotheses were formulated.

$\mathrm{H}_{\mathrm{o} 1}$ : There is no significant contribution of family-friendly human resource practice to employee's behavioral outcomes (organizational commitment, job performance and workplace spirituality) among bankers in Nigeria.

$\mathrm{H}_{\mathrm{o} 2}$ : There is no significant relationship between family-friendly human resource practice and employees behavioral outcomes (organizational commitment, job performance and workplace spirituality) among bankers in Nigeria.

$\mathrm{H}_{03}$ : There is no significant difference between male and female respondents perception of employees behavioral outcomes (organizational commitment, job performance and workplace spirituality) on the basis of family-friendly human resource practice among bankers in Nigeria.

\section{Methodology}

The research design adopted a descriptive research method because it gives room for accurate description, recording, analyzing and interpretation of gathered information. It also gives the respondents to have equal chance of participation in the study.

The population of the study consists of the entire workers in United Bank for Africa (UBA) in Ogun and Lagos States. For the purpose of the study, both male and female employees that have spent at least two years with the selected bank participated in the study. A simple random sampling technique was used to select 380 for the study. Simple random method was used to ensure randomness among the selected samples.

The instrument to be used in collecting data for investigation was structured questionnaire. The questionnaire consist of four sections namely section A, B, C, D and E. Section A consists of socio-demographic information about the respondents, such as age, marital status, gender, educational qualification, religion, length of service. Section B consists of Family-friendly Human Resource Practice Scale. The scale was based on a 10-item scale. This item contains item relating to FFHRM practice scale the rating of the responses from this instrument was rated on Likert -type scale ranging from SA-Strongly Agree (5), A- Agree (4), D-Disagree (3), SD- Strongly disagree (2), and U-Undecided (1). The overall Cronbach's alpha co-efficient in parentheses indicating the internal consistency reliability of the scale to be $\alpha=0.96$. Section C, D, and E covers areas of employees behavioral outcomes consisted proxy by organizational commitment, job performance, and workplace spirituality.

Section C adopted Organizational Commitment Scale (OCS). This was based on an 11-item scale which includes affective commitment, continuance commitment and normative commitment as developed by Allen and Meyer (1996) but was modified by the researchers for measuring the organizational commitment of workers. These items are measured on Likert type anchored scale from=SA-Strongly Agree (5), A- Agree (4), D-Disagree (3), SD- Strongly disagree (2), and U-Undecided (1). The Cronbach's alpha for organizational commitment in this study is 0.82 .

Section D was Job Performance scale (JSS). This measure was based on a 10-item scale on job performance scale (JSS) which measured the level of performance of employees. The measure was assessed on a modified Likert five-point scale, ranging from $5=$ very satisfied to $1=$ Neutral. The author reported a Cronbach alpha coefficient of 0.86. Section covers Workplace Spirituality Scale (WSS). This was measured on a 10 -item scale of workplace spirituality which measured the level of various aspects of employees' perceptions about their feelings, including meaningful work, sense of community and alignment of values. The responses are measured on Likert type anchored scale from SA-Strongly Agree (5), A- Agree (4), D-Disagree (3), SD- Strongly disagree (2), and UUndecided (1). The overall Cronbach alpha is 0.82

A copy of the questionnaire with a letter of introduction was taken to the United Bank for Africa (UBA) in Ogun and Lagos States for permission to administer the questionnaires among its employees. Individual consent of employees was obtained, as no respondent was forced to complete the filling of the questionnaire administered. All aspects of the instruments were duly explained to the respondents. The whole exercise of data collection spanned between April and May, 2019. Based on the sample size, a total of 380 questionnaires were circulated. At the end, 306 copies were retrieved successfully out of which 239 copies were completely filled, found useable and utilized for the study. The response rate was $62.89 \%$. 
Statistical Package for Social Sciences (SPSS) version 21 was used to analyze the data collected. Pearson Product-Moment Correlation, regression and T-test analyses at 5\% level of significance were used in the analyses.

\section{Results}

The results of the analyzed data were presented on the basis of the hypotheses generated for the study.

$\mathbf{H}_{01}$ : There is no significant contribution of FFHRM practice to employees' behavioral outcomes (organizational commitment, job performance and workplace spirituality)

Table 1. Regression Analysis on contribution of Family-Friendly Human Resource Management Practice to Employees' Behavioural Outcomes

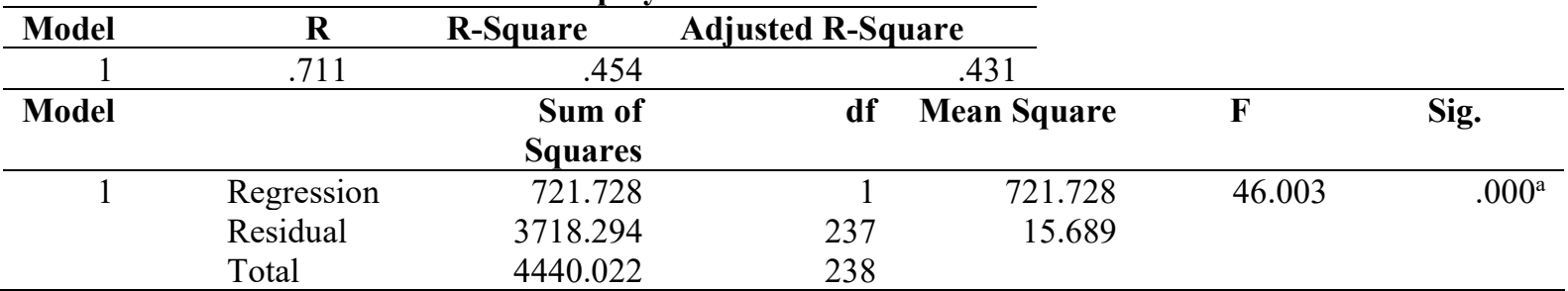

a. Predictors: (Constant), Family-friendly human resource management

b. Dependent Variable: Employees' Behavioural Outcomes

In Table 1, the regression analysis was used to ascertain the contribution of family-friendly human resource management practice to employees' behavioral outcomes (organizational commitment, job performance and workplace spirituality), the results $\left(\mathrm{F}_{(1,239)}=46.003 ; \mathrm{p}<0.05\right)$ indicated that FFHRM have significant contributions on employees' behavioral outcomes. The finding revealed that FFHRM practice accounted for $45.4 \%$ of the total variance in the employees' behavioral manifestation in terms of organizational commitment, job performance and workplace spirituality. The finding revealed further that FFHRM practice was found to be a significant factor in the consideration of organizational commitment, job performance and workplace spirituality at workplace with pvalue less than the value of $\alpha=0.05$ level of significance. The $F_{\text {tabulated }}\left(F_{1,237,0.05}=3.84\right)$ was found to be lesser than $F_{\text {calculated }}\left(F_{1,237,0.05}=46.003\right)$, which indicated that enough evidence against the null hypothesis, hence, it was rejected and concluded that there is significant contribution of FFHRM practice to employees' behavioral outcomes among bankers in Nigeria.

H02: There is no significant relationship among family-friendly human resource management practice, and employees' behavioral outcomes among bankers in Nigeria.

Table 2. Summary of Pearson Product Moment Correlation Showing the Relationship among Family-

Friendly Human Resource Management Practice, Organizational Commitment, Job Performance and Workplace Spirituality

\begin{tabular}{|c|c|c|c|c|c|}
\hline & & FFHRMP & EBO1 & EBO2 & EBO3 \\
\hline \multirow[t]{4}{*}{ FFHRMP } & Pearson & 1 & & & \\
\hline & Correlation & & & & \\
\hline & Sig. (2-tailed) & 239 & & & \\
\hline & $\mathrm{N}$ & & & & \\
\hline \multirow[t]{4}{*}{ EBO1 } & Pearson & $.461 * *$ & 1 & & \\
\hline & Correlation & .001 & & & \\
\hline & Sig. (2-tailed) & 239 & 239 & & \\
\hline & $\mathrm{N}$ & & & & \\
\hline \multirow[t]{4}{*}{$\mathrm{EBO} 2$} & Pearson & $.327 * *$ & .204 & 1 & \\
\hline & Correlation & .000 & .061 & & \\
\hline & Sig. (2-tailed) & 239 & 239 & 239 & \\
\hline & $\mathrm{N}$ & & & & \\
\hline \multirow[t]{4}{*}{ EBO3 } & Pearson & $.253 * *$ & .105 & .471 & 1 \\
\hline & Correlation & .001 & .512 & .042 & \\
\hline & Sig. (2-tailed) & 239 & 239 & 239 & 239 \\
\hline & $\mathrm{N}$ & & & & \\
\hline
\end{tabular}

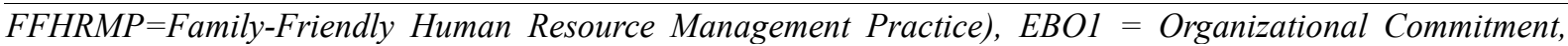
EBO2 = Job Performance, EBO3 = Workplace Spirituality, and EBO = Employee Behavioural Outcomes **, Significance at 0.05 level of significance

The results in Table 2 indicates that family-friendly human resource management practice has a significant positive relationship with organizational commitment $(\mathrm{r}=.461 ; \mathrm{p}<0.05)$, job performance $(\mathrm{r}=.327 ; \mathrm{p}<0.05)$, and workplace spirituality $(\mathrm{r}=.253 ; \mathrm{p}<0.05)$.

Ho3: There is no significant gender difference between employees' behavioral outcomes (organizational commitment, job performance and workplace spirituality) of male and female respondents on the basis of family- 
friendly human resource management practice among bankers in Nigeria.

Table 3. Table of t-test Analysis on Gender Differences and Employees' Behavioural Outcomes of Male and Female Respondents on the Basis of Family-Friendly Human Resource Management Practice

\begin{tabular}{llrllllll}
\hline Variable & Gender & N & Mean & SD & df & t & p & Remark \\
\hline EBO1 & Male & 143 & 20.45 & 11.88 & 239 & 17.05 & .000 & Significant $(\mathrm{p}<0.05)$ \\
& Female & 94 & 21.56 & 12.34 & & & & \\
EBO2 & Male & 143 & 24.12 & 9.76 & 239 & 15.78 & .001 & Significant $(\mathrm{p}<0.05)$ \\
& Female & 94 & 22.77 & 12.34 & & & & \\
& Male & 143 & 24.65 & 11.56 & 239 & 13.67 & .002 & Significant $(\mathrm{p}<0.05)$ \\
& Female & 94 & 24.35 & 12.76 & & & &
\end{tabular}

$E B O 1=$ Organizational Commitment, EBO2 = Job Performance, EBO3 = Workplace Spirituality, and EBO = Employee Behavioural Outcomes, **, Significance at 0.05 level of significance

Table 3 shows that the female respondents were found to be demonstrating organizational commitment $(\mathrm{t}=$ $17.05, \mathrm{p}<.05)$, job performance $(\mathrm{t}=15.78, \mathrm{p}<.05)$, and workplace spirituality $(\mathrm{t}=13.67 ; \mathrm{p}<.05)$ than the male respondents on the basis of family-friendly human resource management practice. The findings showed that there were gender differences between employees' behavioral outcomes (organizational commitment, job performance and workplace spirituality) of male and female respondents on the basis of family-friendly human resource management practice. However, these findings require further empirical verification for possible generalization. Thus, hypothesis three was rejected.

\section{Discussion}

The study hypothesis predicted that there is no significant contribution of family-friendly human resource management practice to employees' behavioral outcomes (organizational commitment, job performance and workplace spirituality). The null hypothesis was rejected. The finding of the study revealed that there was significant contribution of family-friendly human resource management practice to employees' behavioral outcomes (organizational commitment, job performance and workplace spirituality). The finding of this study corroborates the findings of Li, Mai, Yang, and Zhang (2019), Ujma and Ingram (2019), Jawaad, Amir, and Hassan (2019), Aboramadan, Albashiti, Alharazin, and Dahleez (2020) and that of Cherif (2020) who reported that friendly human resource management practice have positive and significant on employees' organizational commitment.

The finding implies that the family-friendly system of human resource management practice with evidence of compensation designed and management adopted in the selected Bank in Ogun and Lagos States, Nigeria has really impacted the employees` organizational commitment, job performance and workplace spirituality. This finding supports the findings of Mekhum (2020) who found out that HRM practices significantly influence employee job performance among employees working in Thailand pharmacy sector.

Furthermore, the finding of the study revealed further that both male and female respondents equally perceived FFHRM management practice as having significant relationship on employees` behavioral outcomes in terms of organizational commitment, job performance and workplace spirituality. In other words, the findings indicated that the family-friendly human resource management practice as significant factor in the consideration of employees` behavioral outcomes.

In essence, the respondents perceived the organizational treatment and reward meted out for employees, when compared to the strength of service being rendered to the organizations as fair and equitable. The finding corroborates Akintayo and Babajide (2007); Keashley, Nicolas, and Cleeve (1994); Cobb and Frey (1996), Fry and Gordon (1989), who reported that employees' perception of fair treatment, career development and progression, fair performance appraisal, harmonious labour management relations and multiple functions training and development in an organization tends to influence organizational commitment, JS and performance on the job.

However, the finding of the study disagrees with Clement (2009), Haniseh and Hulins (1990), who contended that human resource management practice within an organization is significantly related to organizational cynicism, withdrawal and turnover behaviours. The finding of the study implies that the family-friendly human resource management practice tends to positively and negatively influence human resource behaviour (job performance, organizational commitment and workplace spirituality).

In essence, respondents perceived equally the impact of FFHRM on employees' behavioral outcomes on the basis of gender. This implies that the male and female respondents' contributions to the growth of their organizations were as a result of their positive perception of the family-friendly human resource management practice in terms of recruitment and promotion policies, equitable reward policy, fair employees ' performance appraisal and treatment in their organizations.

By implications, this study is designed to create awareness on the part of the managers on the needs to pay attention to the policies and procedures related to FFHRM practice. It is important that organization should examine policies and procedures it implements to see if they are in alignment with and enhances the social exchange relationship. Management needs to ensure that the employees are given a "voice" in the process, that 
their input is valued, resulting in the employee perceiving the procedure (the family-friendly human resource management practice) as fair and hence will be more satisfied with their managers and have greater commitment to the organization (Meyer and Allen, 1997). When employees are committed, they identify themselves as being part of the organization, reciprocity and a social exchange relationship exists by creating a sense of fellowship (Meyer \& Allen, 1997).

Some considerations could be given to managers receiving the family-friendly human resource management practice, increasing their fairness behaviour, to improve the social relationships between managers and employees, which could improve the workplace spirituality. Consequently, the managers would spend "less time, effort, and expense on problems with conflict resolution (Ojo, 2009). Indeed, the research of O'Driscoll and Beehr (2003) indicate the effects of the actions of managers upon the organizational employees in shaping their attitudes of organizational commitment and job performance. Thus, the results show that levels of organizational commitment and job performance tend to increase if the human resource perceives that the procedures and outcomes, the familyfriendly human resource management practice are effective and fair. Therefore, managers need to ensure that all policies and procedures are based on the principles of the family-friendly human resource management practice.

\section{Conclusion}

The study established that the family-friendly human resource management practice has significantly influenced employees' behaviour outcomes (organizational commitment, job performance and workplace spirituality). The study further showed that family-friendly human resource management practice is a significant factor in the consideration of organizational commitment, job performance and their level of spirituality at workplace. By implication, a positive impact among these four variables is advantageous to any organization as it can enjoy reduced employee turnover, lead to job satisfaction, increased job performance and organizational productivity, goodwill and public image and so on.

\section{Recommendations}

The study recommended that management should encourage and give FFHRM practice the priority it deserves and be willing to carry it out with new ideas. Banks and by extension all organizations should beef up their HRM policies to focus on building a family friendly organizational culture. Policy on flexi work arrangement and work from home should be looked into to instigate employees to see themselves as part of the organization.

\section{References}

Aboramadan, M., Albashiti, B., Alharazin, H., \& Dahleez, A. (2020). Human resources management practices and organizational commitment in higher education: the mediating role of work engagement. International Journal of Educational Management, 34(1), 154-174. DOI: 10.1108/IJEM-04-2019-0160

Adams, A. G., King, L. A., \& King, D. W. (1996). Relationships of job and family involvement, family social support, and work-family conflict with job and life satisfaction. Journal of Applied Psychology, 4(4), 411420 .

Ajibola, K. S., Mukulu, E., \& Simiyu, A. (2019). Performance appraisal and employee engagement: Does tenure matters? Evidence from South-West Nigeria. Quest Journal of Management and Social Sciences, 1(2), 146164. DOI: 10.3126 /qjmss.v1i2.27415

Akintayo, D.I. \& Babajide. E.O. (2007). Human resource management practice and employees' job performance effectiveness in work organizations in southwest Nigeria. International Journal of Management, 23(3), 4554.

Allen, N. J. \& Meyer, J. P. (1996). Affective, continuance, and normative commitment to the organization: An examination of construct validity. Journal of Vocational Behavior , 49, 252-276.

Beehner, C. G. (2019). Spirituality, Sustainability, and Success: Concepts and Cases. Switzerland: Palgrave Macmillan. doi:10.1007/978-3-319-77806-8

Biswakarma, G. (2018). Impact of workplace spirituality on employee productivity in Nepalese hospitality organizations. Journal of Tourism and Hospitality Education, 8(2018), 62-76.

Cambridge Advanced Learner's Dictionary and Thesaurus. (2020). Dictionary. Cambridge University Press. Retrieved March 3, 2020, from https://dictionary.cambridge.org/dictionary/english/work-life-balance

Chatterjee, A., \& Naqvi, F. (2010). Spirituality in organizational life: an empirical study of spirituality and job attitudes. Abhigyan 28(3), 18-29.

Cherif, F. (2020). The role of human resource management practices and employee job satisfaction in predicting organizational commitment in Saudi Arabian sector. International Journal of Sociology and Social Policy. DOI: 10.1108/IJSSP-10-2019-0216

Clement, A. R. (2009). Management theory: Functional approach. London: Sage Publications

Cobb, S.F. \& Frey, W. (1996). Human resource management and employees' career progression in male dominated organization. Journey of Social Sciences, 9(1), 67-84. 
Cook, V. (2019). Spiritual Socialists: Religion and American Left. Philadelphia, PA: University of Pennysylvania Press.

Dehaghi, M. R., Goodarzi, M., \& Arazi, Z. K. (2012). The effect of spiritual values on employees' organizational commitment and its models. Procedia - Social and Behavioral Sciences, 159-166. doi:10.1016/j.sbspro.2012.09.025

Dessler, G. (2017). Human Resource Management (15th ed.). New York: Pearson Education Inc.

Dick, J. (2011). Telecommuting: A manager's guide to flexible work arrangements. New York: Lexington.

Fry, F.S. \& Gordon, P. (1989). Fundamentals of human resource management. Journal of Human Resource Management, 18(2), 77-85.

Garrido, M. L. B. (2016). The effect of family-friendly policies on job satisfaction. Master's Thesis, Universitat de les Illes Balears,

Giacalone, R., \& Jurkiewicz, C. (2010). Handbook of Workplace Spirituality and Organizational Performance. Armonk, NY: M. E. Sharpe

Gutek, B. A., Searle, S., \& Klepa, L. (2009). Rational versus gender role explanations for work-family conflict. Journal of Applied Psychology, 76(4), 560-568.

Hammer, L. B., Neal, M. B., Newsom, J. T., Brockwood, K. J. \& Colton, C. L. (2005). A Longitudinal study of the effects of dual-earner couples' utilization of family-friendly workplace supports on work and family outcomes. Journal of Applied Psychology, 90, 799-810.

Haniseh, Y. \& Hulins, W. O. (1990). Organizational psychology. New Jersey: Publishing House.

Jawaad, M., Amir, A., Bashir, A., \& Hasan, T. (2019). Human resource practices and organizational commitment: the mediating role of job satisfaction in emerging economy. Cogent Business \& Management, 6(1), 1-22. DOI:10.1080/23311975.2019.1608668

Jianglin, K. E. \& Xiuting, D. (2018) Family-friendly human resource practice, organizational commitment, and job performance among employees: The mediating role of workplace spirituality. Journal of Human Resource and Sustainability Studies, 81-91.

Keashley, D. P., Nicolas, G. T. \& Cleeve. B. U. (1994). Employees' training and development as correlate of organizational performance: Empirical evidence from Jordan. Journal of Applied Psychology, 15(2), 122-131

Khanka, S. S. (2014). Business Ethics and Corporate Governance (Principles and Practices). New Delhi, India: S. Chand Publishing.

Kinjerski, V., \& Skrypnek, B. J. (2004). Defining spirit at work: Finding common ground. Journal of Organizational Change Management, 17(1), 26-42. DOI: 10.1108/09534810410511288

Kirton, G. (2017). Work-Life Balance: National regimes, organizational policies and individual choices. In A. Wilkinson, T. Redman, \& T. Dundon, Contemporary Human Resource Management (pp. 333-351). Harlow, England: Pearson.

Kopelman M., Kossek K. \& Ozeki P., (2006). An empirical study on exploration of work life balance in innovation in management challenges and opportunities in the next decade, the handbook of Workplace Spirituality and Organizational Performance, 3-28.

Li, X., Mai, Z., Yang, L., \& Zhang, J. (2019). Human resource management practices, exhaustion, and organizational commitment - with example of the hotel industry. Journal of China Tourism Research, 115.DOI: $10.1080 / 19388160.2019 .1664960$

Mekhum, W. (2020). The influence of effective human resource management practices on organizational performance in the Pharmacy Sector of Thailand. Systematic review Pharmacy, 11(3), 195-204.

Meyer, J. P., \& Allen, N. J. (1997). Commitment in the workplace: Theory, research and application. Newbury Park, CA: SAGE.

Motowidlo, S. J., Barman, W. C. \& Schmit, M. J. (1997). A theory of individual differences in task and contextual performance, Journal of Human Performance.

Noe, R. A., Hollenbeck, J. R., Gerhart, B., \& Wright, P. M. (2016). Fundamentals of Human Resource Management (6th ed.). New York, NY: McGraw Hill Education.

O'Driscoll, S.H \& Beehr, H.I. (2003). Human resource management. (3rd ed.). New York, NY: Prentice Hall.

Ojo, O. K. (2009). Impact of performance appraisal on employees' effectiveness. Nigerian Journal of Management Sciences, 7(2), 23-31.

Platow, M. M., Wenzel, M. \& Nolan, M. (2003). The Importance of social identity and self-categorization processes for creating and responding to fairness: Social Identity at Work, 261-276.

Rego, A. \& Cunha, M.P. (2008). Workplace spirituality and organizational commitment: An empirical study. Journal of Organizational Change Management , 21,53-75.

Riasudeen, S. \& Prabavathy, R. (2011). Relationship of workplace spirituality and work attitude in manufacturing organization. Global Management Review, 5, 29-37.

Rotundo, M. \& Sackett, P. R. (2002). The relative importance of task, citizenship, and counterproductive performance to global aspects of job performance: A policy-capturing approach. Journal of Applied 
Psychology, 87, 66-80.

Shinde, J., Shinde, U., \& Lytle, L. (2010). The impact of organizational spirituality on employee outcomes. International Journal of Academic Business World, 4(2), 121-129.

Smith, J. A., \& Rayment, J. J. (2007). The global SMP fitness framework: A guide for leaders exploring the relevance of spirituality in the workplace. Management Decision, 45(2), 217-234.

Ujma, M., \& Ingram, T. (2019). Perception of ability-motivation-opportunity oriented HRM practices and organizational commitment: The role of task uncertainty. Journal of Entrepreneurship, Management and Innovation, 15(1), 139-162.

Veiga, J. F., Baldridge, D. C., \& Eddleston, K. A. (2004). Toward understanding employer reluctance to participate in family-friendly programs. Journal of Human Resource Management review, 14, 337-351. 